\title{
ALTERED SPERMATOGENESIS IN THE HYPODACTYLOUS RATS
}

\author{
Zuzana Jirsováa ${ }^{a}$ Tomáš Kučera ${ }^{\mathrm{a}}$, Jindřich Martínek ${ }^{\mathrm{a}}$, František Liška ${ }^{\mathrm{b}}$, Drahomíra Křenováb, \\ Vladimír Křen ${ }^{\mathrm{b}}$
}

a Institute of Histology and Embryology,

${ }^{b}$ Institute of Biology and Medical Genetics, $1^{\text {st }}$ Faculty of Medicine, Charles University, Albertov 4, 12801 Prague 2, Czech Republic

e-mail: zuzana.jirsova@lf1.cuni.cz

Received: September 20, 2004

Key words: Rat hypodactyly/Altered spermatogenesis/Apoptosis

Germinal epithelium of seminiferous tubules in adult, infertile hypodactylous males displays significant reduction in the number of germ-line cells. Detection of apoptosis in the germ-line cells during postnatal differentiation was performed to elucidate the mechanism of the decreased number of germ cells in the testes of adult rats. Evaluation of DNA fragmentation and expression of activated caspase-3 in germ cells did not confirm marked germ cell death during the onset of spermatogenesis as a main cause of significant reduction of germ cells in $H d / H d$ testes of adult males. The primary cause of spermatogenesis deffect seems to be rather associated with a disorder in the cell cycle regulation and interrelation of germ-line cells with Sertoli cells.

\section{INTRODUCTION}

Rat autosomal recessive hypodactylous $(H d)$ mutation leads to male sterility of the homozygotes, which is associated with a significant decrease in the number of germ cells ${ }^{1,2}$. The present study was aimed at establishing whether increased germ cell degeneration during differentiation of seminiferous epithelium is a dominant cause of this disorder.

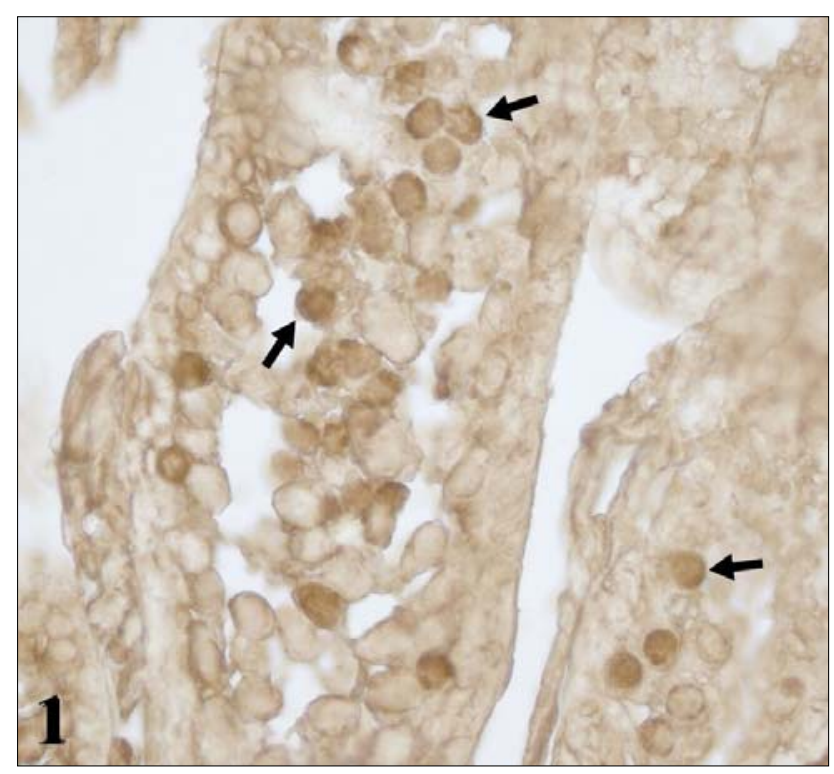

Fig. 1. Clusters of apoptotic spermatocytes (arrows) in the luminal area of seminiferous tubules. TUNEL Assay, 18-day old $+/ H d$ male. $400 \mathrm{x}$.

\section{MATERIAL AND METHODS}

The testes of juvenile and adolescent $H d / H d$ and $+/ H d$ rats were processed for light and electron microscopy. Evaluation of apoptosis was performed by the detection of DNA fragmentation using the TUNEL Assay and by immunohistochemical detection of activated caspase- 3 in the germinal epithelium.

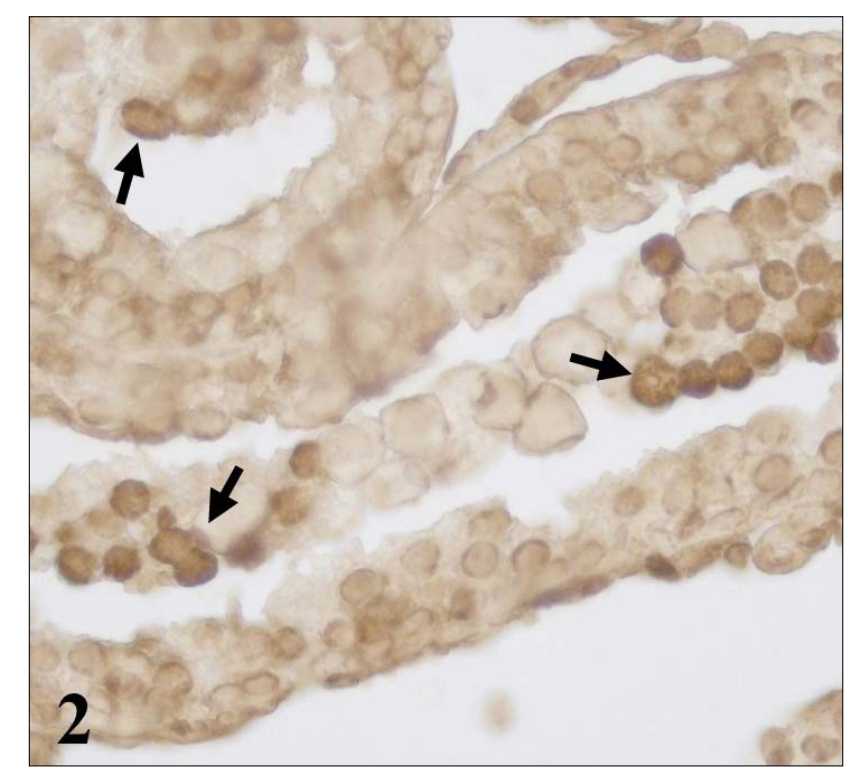

Fig. 2. TUNEL positive cells (arrows) of 18-day old rat in the lumen of $H d / H d$ seminiferous tubules. $400 \mathrm{x}$. 


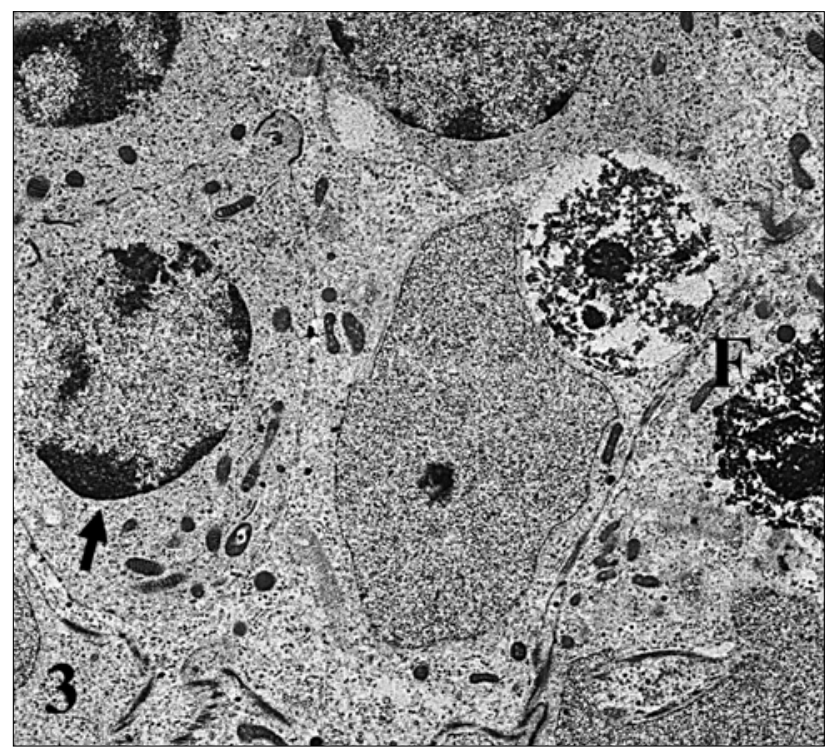

Fig. 3. Apoptotic cells in the $H d / H d$ tubule of 18-day old rat. Arrow = initial stage, arrowhead = intermediate stage of apoptosis, $\mathrm{F}$ = phagosome in Sertoli cell. $4,400 x$.

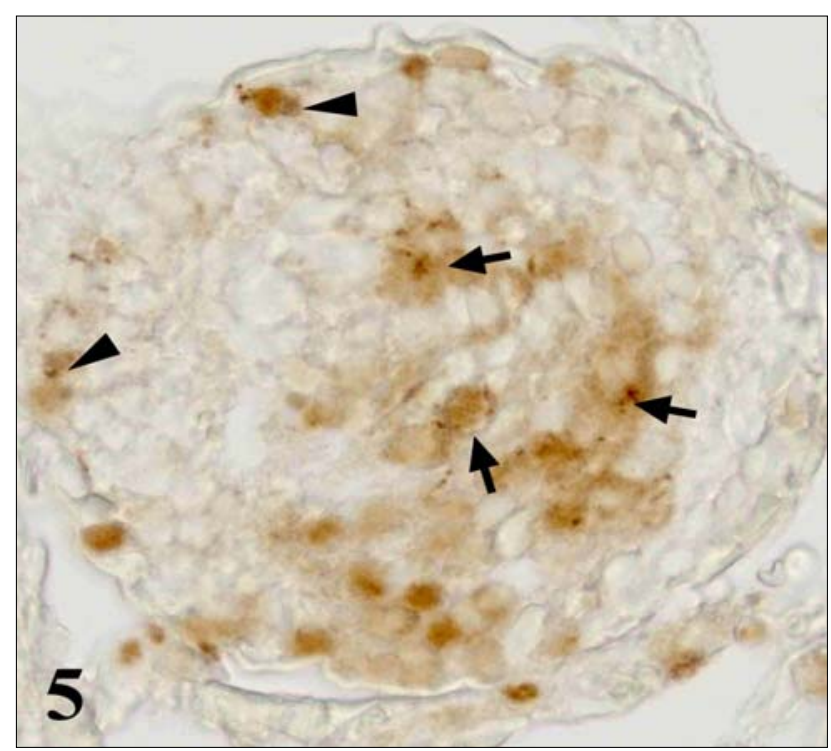

Fig. 5. Expression of activated caspase- 3 in spermatocytes (arrows) and spermatogonia (arrowhead). Seminiferous tubule of 33-day old $+/ H d$ male. $620 \mathrm{x}$.

\section{RESULTS AND DISCUSSION}

Seminiferous tubules of 3-week old rats displayed two generations of germ line cells, spermatogonia and primary spermatocytes. The onset of spermatogenesis was accompanied by germ cell degeneration; apoptotic spermatocytes, detected by TUNEL Assay, were found mainly as clusters in the luminal area of some tubules. However, no significant differences between the $H d / H d$ and $+/ H d$ testes were confirmed (Fig. 1, 2). Apoptotic germ cells

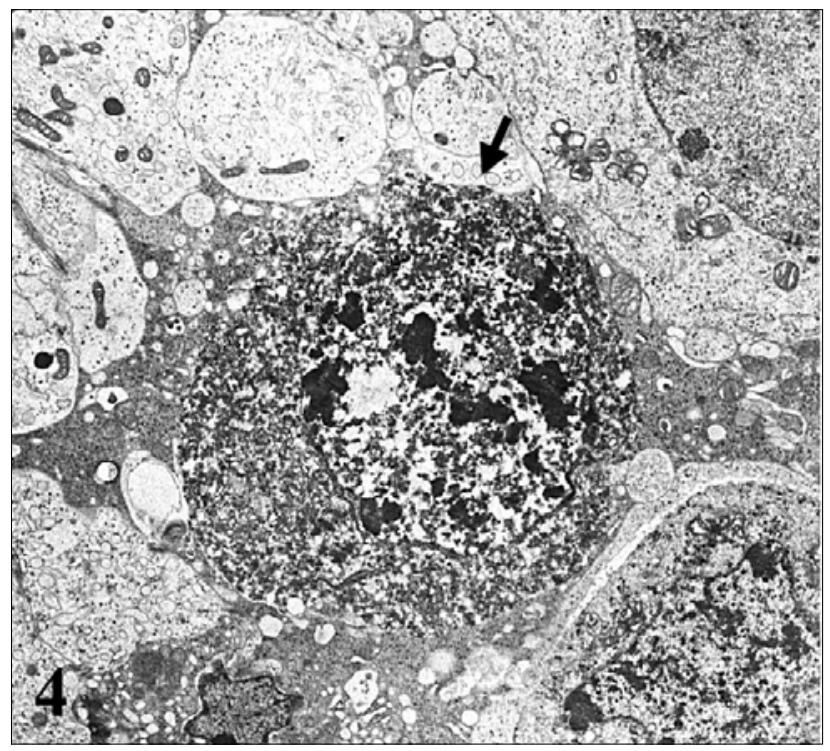

Fig. 4. Apoptotic spermatocyte (arrow) in the lumen of + / $H d$ seminiferous tubule of 21 day old rat. $3,900 \mathrm{x}$.

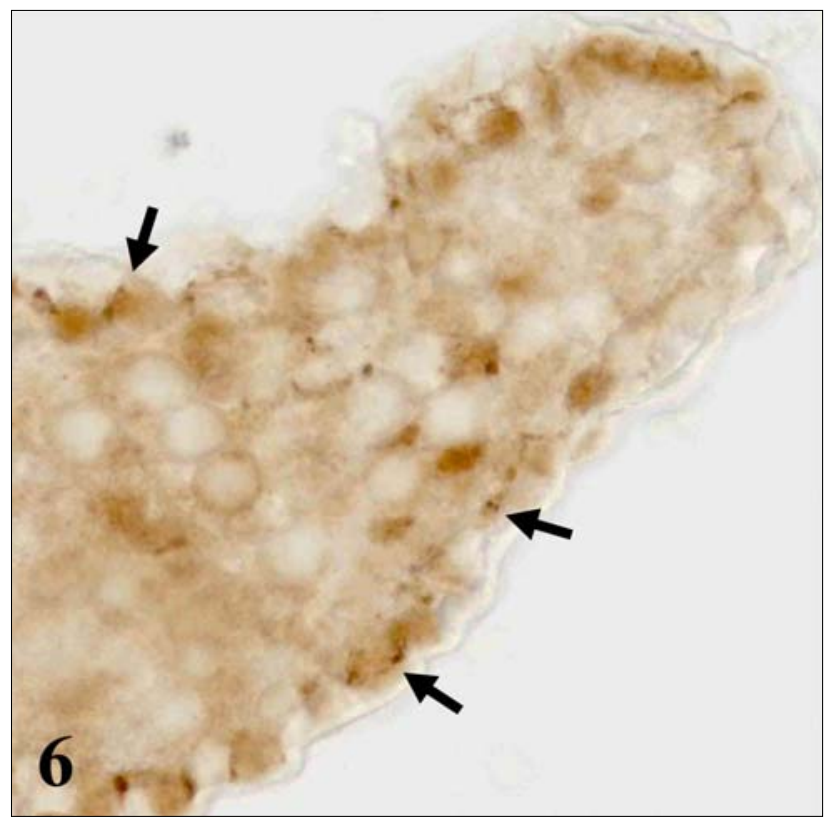

Fig. 6. Detection of activated caspase-3 in spermatogonia (arrows). Seminiferous tubule of 33-ay old $\mathrm{Hd} / \mathrm{Hd}$ male. $620 \mathrm{x}$.

appeared to be eliminated either into the tubule lumen and/or by Sertoli cell phagocytosis (Fig. 3, 4). The structure of the testis in $\mathrm{Hd} / \mathrm{Hd}$ maturing rats corresponded to previous findings in adult males ${ }^{2}$. Numerous tubules were lined with loosed germinal epithelium, displaying a decrease in number of differentiating germ cells; only local spermatogenic areas were observed. Expression of activated caspase-3 in the cytoplasm of germ-line cells was lower in comparison with $+/ H d$ testes (Fig. 5). Positive findings of caspase -3 in $H d / H d$ testes were detected in 
sparse tubules only and were associated predominantly with spermatogonia (Fig. 6). Elevated rates of apoptosis in seminiferous epithelium of $+/ H d$ testes seem to be associated with enhanced proliferation of germ cells in maturing fertile males.

\section{ACKNOWLEDGEMENTS}

Supported by the Grant Agency of the Czech Republic (Grant No. 301/02/0464).

\section{REFERENCES}

1. Křenová $\mathrm{D}$, Jirsová Z, Bílá $\mathrm{V}$, Kašpárek R, Pravenec $\mathrm{M}$, Křen V. (2002) Genetics of hypodactyly. J Exp Anim Sci 41: 41.

2. Jirsová Z, Martínek J, Liška F, Křenová D, Křen V. (2001) Cytological changes of altered spermatogenesis in rat hypodactylous mutation. Histochem J 33: 498. 